\title{
Countermeasure Suggestion and Mechanism System Innovation for Comprehensive Utilization of Dredged Mud in Shanghai
}

\author{
WANG Cun-shi ${ }^{1, a}$, SHI Dan-da ${ }^{1, b}$, ZHAO Yong-quan ${ }^{2, c}$, LIU Wen ${ }^{2, d}$ \\ ${ }^{1}$ College of Ocean Science and Engineering, Shanghai Maritime University, China \\ ${ }^{2}$ School of economic \& management, Shanghai Maritime University, China \\ acswang1992@163.com, ${ }^{\mathrm{b}}$ shidanda@163.com, ${ }^{\mathrm{a}}$ zhyongquan@163.com, ${ }^{\mathrm{d}}$ 409737555@qq.com,
}

\begin{abstract}
Keywords: Dredged mud; Comprehensive utilization; Countermeasure suggestions; System mechanism innovation

Abstract. Through the analysis of the status quo of Shanghai dredging mud comprehensive treatment, combined with the domestic and international successful cases, and summing up the experience of previous engineering, puts forward the countermeasures and Suggestions of comprehensive utilization in conformity with the practical situation of Shanghai. Based on the mechanism of the system at the same time, from the market economy, the industrial development, policy basis gives some specific and innovation, to promote the reasonable utilization of dredged mud resources, improve the level of Shanghai's comprehensive utilization of dredged mud.
\end{abstract}

\section{Comprehensive utilization status of dredged clay and existing problems in Shanghai}

Most dredged mud in Shanghai comes from the dredging and dredging works in the Shanghai section of the Yangtze River. The dredged sediment in this area is clean and is a strategic resource that can be effectively utilized ${ }^{[1]}$. In recent years, Shanghai has vigorously constructed dredging of harbors and channels, and with the continuous promotion of the "National Coastal Harbor Layout Plan," the total amount of dredged mud produced will also have room for improvement. In the area of the Yangtze River estuary in Shanghai, at present the $12.5 \mathrm{~m}$ deepwater channel in the Yangtze Estuary and the Waigaoqiao Port Area in Shanghai Port accumulate nearly 80 million $\mathrm{m}^{3}{ }^{[2]}$.

Prior to 2004, dredged mud in Shanghai had been piled on land or dumped into the sea as waste. In the second phase of the Yangtze Estuary Deepwater Channel Regulation Project, the Shanghai Waterway Bureau first dredged mud to fill the Hengsha East Beach. In 2010, under the support of the Ministry of Transport and the Shanghai Municipal People's Government, the Changjiang Estuary Channel Authority and the Shanghai Municipal Development and Reform Commission signed the Memorandum of Understanding on Jointly Promoting the Comprehensive Utilization of Dredging Soil along the Channel of the Yangtze Estuary, and established the utilization of dredged dumped mud Scientific research mechanisms to accelerate the dredging mud land use ${ }^{[3]}$. In 2013, the Ministry of Communications and the Shanghai Municipal People's Government jointly issued the Opinions on Implementing the Overall Plan of the China (Shanghai) Pilot Free Trade Zone, Accelerating the Construction of Shanghai International Shipping Center and put forward the proposal of "strengthening the integration of the dredger soil in the Yangtze Estuary Deepwater Channel Use and better serve the development of Shanghai International Shipping Center "[4]. Part of the dredged mud produced by the Yangtze Estuary Deepwater Channel Regulation Project is used as a filler in the area around the Dongtan Circle of Hengsha ${ }^{[5]}$.

In addition, on the comprehensive utilization of dredged sediment exploration. Chen Qingze et al (1992) ${ }^{[6]}$ select the dredged mud of the Yangtze River Estuary effective components, obtained after high temperature treatment of blue pigment. Xie Jian et al. (2004) ${ }^{[7]}$ mixed marine dredging clay with clay to produce lightweight ceramsite. Li Yang et al. (2014) ${ }^{[8]}$ adopted a method of chemical solidification to prepare a dredged solidified prefabricated block and a hexagonal nut slope protection block.

Similar to most coastal cities in China, there are still many problems in the comprehensive utilization of dredged sediment in Shanghai: processing equipment is relatively backward, technical 
standards are still to be improved, the industrial chain is in its infancy, government tendencies are low, incentive policies and laws and regulations are lacking Sex and so on. This paper firstly put forward some countermeasures and suggestions on the comprehensive utilization of dredged sediment from the aspects of economy, feasibility and environmental protection. Secondly, it sorts out the existing institutional problems. At last, City Dredging Industry Development Suggestions and Solutions.

\section{To strengthen the system construction, and create a good policy environment}

The formation and development of any emerging industry can not be separated from the guidance of the government and the support of policies. The road to industrialization is still difficult. The Shanghai municipal government should actively cooperate with relevant laws and regulations and implement the management measures. At the same time, make the following basic suggestions:

\section{Dredged resources utilization of green grants funding}

Set up a special fund for the utilization of dredged mud resources. Due to the high level of government administration and the complicated departments, superior financial appropriations and project appropriations for lower levels often need to be declared in advance, and the examination and approval procedures are complicated. Therefore, it is very difficult for financial subsidies to be implemented on time. This will to some extent affect the enthusiasm of enterprises. In order to ensure the smooth implementation of the utilization of dredged sediment, government departments should calculate the reasonable amount of subsidies, make public to the public, set up special dredged mud and use subsidies to launch the green channel for financial allocation. Governments at all levels should make good financial budget in advance according to the amount of subsidies and the goal of utilization of dredged soils, report to the agencies or departments at a higher level, and audit them at a higher level as soon as possible, make timely appropriation and follow-up.

\section{Dredged sediment collection - storage - the use of system construction}

Dredged mud in Shanghai is rich in resources, but for a long time dredged mud has been mostly used for direct landfill and land reclamation. The overall waste phenomenon is more serious. Dredged sludge utilization of resources on environmental protection, energy saving has a great role in promoting. Dredged silt collection - storage - the use of the system construction should have a clear goal, a clear system of the main construction, topics and related supporting elements to promote the full functioning of the system. This requires establishing a reasonable organizational structure, improving the operational structure of the organization, clarifying the organizational objectives, promoting the competitiveness of the dredged mud system through the role of the market, and constantly improving the organizational structure in the competition. On the other hand, the Shanghai municipal government should give full play to the macro The main body of the role of regulation, through the relevant policy support, guidance and support services to follow up, build economic and environmental benefits of a unified dredging mud comprehensive utilization system.

\section{To help businesses promote dredged mud products}

Relevant departments of Shanghai municipal government can dredge mud products for environmental testing, the dredged mud products labeled green logo, which is conducive to gain the trust of consumers, in similar products to make it more competitive. At the same time, municipal engineering in Shanghai should give priority to purchasing dredged mud products. In order to encourage dredging mud producers, the Shanghai municipal government can list relevant dredged mud products produced in various districts in Shanghai's priority purchase list, which can effectively increase the sales volume of enterprises and encourage more enterprises to explore the utilization of dredged mud. 


\section{Innovation mechanism system to promote the dredging industry}

The industrialization of dredged mud resources is a complicated systematic project involving the dredging mud providers, recipients and users. Whether this emerging industry integrating environmental protection and economic benefits can be developed depends not only on its utilization value but also on the government's policy preference to a large extent. It also requires a large number of industries including shipping channels, environmental protection, marine resources and land resources Close cooperation and consultation of departments In order to promote the industrialization process, put forward the following countermeasures and suggestions:

\section{Establish dredging mud supply and demand coordination platform}

Establish a communication and coordination platform for supply and demand information, construct information exchange channels for dredging mud suppliers and recipients and marketing parties of relevant products, and timely grasp the occurrence of dredging mud in Shanghai and do a good job of dredging mud disposal plans and comprehensive utilization plans. Analysis of foreign cases ${ }^{[9-12]}$, dredged mud between the provider and the user can keep the flow of information in a timely manner, whether it can smoothly promote the comprehensive utilization of dredged sludge industrialization of the important factors. Shanghai currently lacks the necessary information and coordination of the supply and demand institutions or platforms, dredging mud resources can not do point to point digestion and absorption.

\section{Clear dredging mud management department, improve the relevant laws and regulations}

The current management of the comprehensive utilization of dredged silt is divided into contradictions and conflicts, involving multiple levels and departments. It involves the Ministry of Transport and Shanghai Municipality, the relevant enterprises and units in the vertical direction, and transverses the water transport, water conservancy and land resources , Marine, agriculture, environmental protection and other regulatory agencies, and all departments have the corresponding laws and policies in the management of dredged mud redundant and complex. Therefore, the establishment of a clear department responsible for the comprehensive utilization of dredged mud, streamline processes and improve the management efficiency of comprehensive utilization. Development of dredged mud dynamic information management system, real-time input and publish the source of dredged mud, whereabouts, types, etc., digital, sophisticated and efficient management.

\section{Conclusions}

Although the dredging mud utilization in our country started relatively late, but in recent years the trend of development faster. Located in the mouth of the Yangtze River, Shanghai is also an international shipping center vigorously built by the country. After the relevant laws and regulations are gradually perfected, the institutional mechanisms are continuously improved, and the market economy is relatively stable, the industrial chain of dredging and comprehensive utilization of mud is bound to be shaped healthily. "Green Water Castle Peak is Yinshan Jinshan", the state has always attached great importance to resource conservation and environmental protection work. In the future, the direction of comprehensive utilization of dredged sediment will also tend to be resource-saving and environment-friendly, and the Shanghai municipal government and units at all levels should make deployment and planning as soon as possible.

\section{Acknowledgements}

This work was financially supported by the Shanghai Science and Technology Innovation Action Plan Soft Science Research Key Project (No. 16692105400) 


\section{References}

[1] Zhao Dezhao, Yang Yijian.Framework Suggestion on Beneficial Use of Dredged Material at the Shanghai reach of Yangtze River [J]. Hydro-Science and Engineering, 2015 (1): 82-88.

[2]Zhao Dezhao, Liu Jie, Zhang Junyong, et al. Supply and demand of sediment resources in the Yangtze River Estuary under the new situation and optimal allocation [J]. Journal of Sediment Research, 2011 (6): 69-74.

[3] Wang Weiwei, Pu Xun, Zhao Nan. Prospect Analysis of Reclamation Projects Using Dredged Spoils in Shanghai[J] . Advances in Science and Technology of Water Resources, 2013 (3): 68-71.

[4] Explore innovative shipping development system model, speed up the construction of Shanghai International Shipping Center [N]. China Communications, 2013-9-30.

[5] GAO Min, ZHU Jian-fei. Prospect and current situation of the beneficial use of dredging material in the improve project entitlement of the deep-draft channel of Yangtze Estuary [C] // World Organization of Dredging Associations. Proceedings of the 19 World Dredging Congress. Beijing, 2010: 252-255.

[6] Chen Qingze, Chen Banglin. Changjiang estuarine sparse soil made of fine chemical products [J] Marine Sciences, 1994 (2): 45-46.

[7] Xie Jian, Lin Xincheng, Shi Ping, Wan Derong, Chen Wei. Study on Using Sea Mud to Produce Light Weight Aggregate[J] . Journal of Zhanjiang Ocean University | J Zhanjiang Ocean University, 2004,24 (6): 32-36.

[8] LI Yang, ZHU Sheng-sheng.Development and Demonstration Application of Dredged Clay Solidification Engineering Preform [J] . China Concrete and Cement Products, 2014 (5): 38-41.

[9] Li Tao, Zhang Zhihong, Tang Baorong. Process and Practice of Landfill Dredging Polluted Sediment in Holland [J] .Environmental Engineering, 2006,24 (4): 48-55.

[10] Harbor Bureau, Ministry of Land, Infrastructure, Transport and Tourism. Technical guide on the discharge of dredged soil into the ocean and its efficient use [R]. Japan: Harbor Bureau, Japan's Ministry of Land, Infrastructure and Transport.

[11] US Enviromental Protection Agency, US Army Corps of Engineers. Identifying, Planning, and Financing Beneficial Use Projects Using Dredged Material, Beneficial Use Planning Manual [S].

[12] Welp T, Palermo M, Landin M, et al. US Army Corps of Engineers new dredging engineer manual "Dredging and Dredged Material Placement" [C] // American Society of Civil Engineers. Proceedings of the 3rd Specialty Conference on Dredging and Dredged Material Disposal, 2002. 